\title{
BROILER MORTALITY AND HUMAN BEHAVIOR AT WORK
}

\author{
Maria do Carmo Baracho de Alencar'; Irenilza de Alencar Nääs²*; Douglas D’Alessandro \\ Salgado $^{2}$; Leila Amaral Gontijo ${ }^{3}$ \\ ${ }^{1}$ Universidade Tuiuti - Faculdade de Fisioterapia, Rua Marcelino Champagnat 505. 37200-000 - Curitiba, PR - \\ Brasil. \\ ${ }^{2}$ UNICAMP/FEAGRI, C.P. 6011 - 13083-930-Campinas, SP - Brasil. \\ UFSC - Depto. de Engenharia de Produção e Sistemas - Centro Tecnológico, Campus Trindade - 88040-900 - \\ Florianópolis, SC - Brasil \\ *Corresponding author <irenilza@agr.unicamp.br>
}

\begin{abstract}
Brazilian broiler industry adds a significant contribution to country's exports, employing around five million workers in the production chain. The human work involves multiple aspects, including values, beliefs related to work, cultural aspects, personality, motivation etc. The aim of this research was to analyze the associations between broiler accumulated mortality and workers' beliefs related to work, and influences of the supervisors. The study took place in the state of Paraná, Brazil involving 80 broiler integrate farms and 60 workers. A pre-elaborated questionnaire was applied to the workers containing questions related to their health and to some beliefs related to work, as an interview where they could express their feelings. The normal tasks were identified and listed as well as the health status of each worker. The most common group health problems were related to muscle skeletal pain in the lumbar region $(53.7 \%)$ with a weekly frequency, and within the last three months. The low back pain was reported mostly in prevalence of chronic pain, probably due to some manual activities such as cleaning of drinkers and feeders. Statistical analysis revealed four beliefs related to the accumulated broiler mortality: the results depend on me (a); the Company is serious (b); the broilers suffer (c); and training is needed to grow broilers (d). Those beliefs related to work were significant in the model that described the accumulated broiler mortality $(\mathrm{ABM})$ as $\mathrm{ABM}=3.28-0.254 \mathrm{a}+0.231 \mathrm{~b}+0.336 \mathrm{c}-0.152 \mathrm{~d}$. There are associations between beliefs related to work, supervisor style, and broiler accumulated mortality. Key words: broiler production, ergonomics, human work
\end{abstract}

\section{MORTALIDADE DE FRANGOS DE CORTE E COMPORTAMENTO HUMANONOTRABALHO}

RESUMO: A indústria avícola brasileira de frango corte tem significativa contribuição na pauta de exportação do país, empregando cerca de cinco milhões de pessoas na cadeia produtiva. O trabalho humano envolve múltiplos aspectos incluindo valores, crenças relacionadas ao trabalho, aspectos, personalidade, motivação etc. O objetivo desta pesquisa analisar as associações entre crenças dos trabalhadores relacionadas ao trabalho e a mortalidade acumulada de frangos de corte, e influências de supervisores no trabalho. O estudo ocorreu em 80 granjas integradas no estado do Paraná, Brasil, envolvendo 60 trabalhadores. Um questionário pré-elaborado foi aplicado aos trabalhadores contendo questões relacionadas à sua saúde e às suas crenças relacionadas ao trabalho, aplicado sob forma de entrevista onde eles podiam expressar seus sentimentos acerca do trabalho. As tarefas usuais foram identificadas e listadas, assim como o estado de saúde de cada trabalhador. Os problemas de saúde mais comuns estavam relacionados com dores músculo esqueléticas na região lombar $(53,7 \%)$ com frequiência semanal no período dos últimos três meses. A dor lombar foi mais reportada, resultando na prevalência de dores de caráter crônico, provavelmente devido às atividades manuais de limpeza de bebedouros e comedouros. Aplicando a análise estatística foram encontradas quatro expressões que tiveram relação significativa com a mortalidade acumulada dos lotes de frangos: os resultados dependem de mim (a), a Companhia é séria (b), os frangos sofrem (c), e é necessário treinamento para produzir frangos (d). Estas crenças relacionadas ao trabalho tiveram significância no modelo que descreve a mortalidade acumulada de lotes de frangos (ABM), como: $A B M=3.28-0.254 a+0.231 b+0.336 \mathrm{c}-0.152$ d. Existem associações entre crenças relacionadas ao trabalho, estilo de supervisão no trabalho humano, e os resultados de mortalidade acumulada de frangos de corte.

Palavras-chave: produção de frangos de corte, ergonomia, trabalho humano

Sci. Agric. (Piracicaba, Braz.), v.63, n.6, p.529-533, November/December 2006 


\section{INTRODUCTION}

Broiler production in Brazil is responsible for an income of the order of US\$ 300 million dollars year ${ }^{-1}$, employing approximately five million workers in the production chain. Labor in animal production involves the relationship with living creatures that interact with each other behavior. Nowadays there is a tendency of searching for specific aspects of animal welfare related to productivity levels of flocks and herds (Rushen et al., 1999; Breuer et al., 2000; Hemsworth, 2003; Raussi, 2003). Departure from an ideal environment, management inside housing and its effect on both birds and worker health is well documented in the literature (Hartung \& Seedorf, 1999; Nääs \& Miragliotta, 2000; Alencar et al., 2004).

The meaning of the work has an important value for the laborer, especially the way he/she perceives it, depending on his/her values, beliefs, personality and culture among others. The way the workers execute their tasks may influence their attitudes and behavior, and their behavior may influence the welfare of the animals. Cransberg et al. (2000) studied the influence of labor on the behavior and productivity of broilers and found that the intensity of workers movements had a positive correlation with the bird mortality index for the first weeks.

Motivation towards work induces worker involvement in all procedures and also influences human perceptions, as well as training and emotional state. Several facts interfere in motivation and are related to the supervisor/ manager atitude. For McColl-Kennedy \& Anderson (2002) the behavior of the manager/supervisor is important to reach organizational goals. In broiler production the need of evaluating the influence of worker perception towards bird's welfare is very important.

The objective of this study was to find associations of the labor influence on the broiler accumulated mortality during the production cycle, considering beliefs of the workers that are related to work.

\section{MATERIAL AND METHODS}

The research was carried out in 80 integrated broiler farms of the region of São José dos Pinhais $\left(25^{\circ} 32^{\prime} 05^{\prime \prime} \mathrm{S}, 49^{\circ} 12^{\prime} 23^{\prime \prime} \mathrm{W}\right)$ and Tijuca do Sul (255' $40^{\prime \prime}$ S, 49¹1'56" W), Paraná, Brazil. The definition of an integrated broiler worker assumed in this research represents an individual that worked at least for two years in a system of broiler production in which one day old chicklings and feed rations are offered by a Company, and the final broiler production is acquired by the same Company.
Growth houses of this study were similar, constructed following conventional a design with wooden poles, concrete floor covered with wood shaving. Sides were open and plastic curtains where used to regulate lateral airflow, and the roof consisted of clay tiles. Even though the dimensions (length and width) varied between them they remained within $10 \%$ of variation. The heating used in the first three weeks of chickling growth was mainly made with wood burning ovens. Most feeders and drinkers were filled manually, and after heat removal they hang from the ceiling, while timers were used for controlling light intensity.

The method presented in two phases. The fist, carried out at the beginning, was an Ergonomic Analysis of the Work with observations of the labor carried out in two broiler houses, three times a week during one and half to three hours, during three months. The total data of the 31 broiler houses was recorded within the same period, selecting specific qualitative data. The second phase, consisting of a questionnaire containing items related to health conditions and to beliefs related to work, was adapted from Coleman et al. (2003). A new region was chosen according to specific interests of the integration Company and the questionnaire was applied to the workers who carried out jobs within broiler housings.

Two agricultural technicians supervised the groups of workers, with distinct ways and manners of interacting with them (region A and region B). The company had a region of known better productivity, subscribed as region B. A personal interview was made with each worker for promoting their expressions of specific complains, or any other expression he/she would like to say about his/her tasks.

For the regression analysis 22 beliefs related to work were used: i. the results depend on me; ii. broilers suffer during production; iii. the Company is serious; iv. training is need to produce broilers; v. broiler production is fun; vi. broilers are dirty; vii. broilers are afraid of people; viii. the welfare of the broiler is important; and others. Answers to the questionnaire were standardized as: I agree; I do not agree; or yet I agree in part.

A questionnaire (named Nordic) for muscle skeletal disorders (Wilson \& Corlett, 1992) including region, frequency of pain and others was applied during sampling to all workers regardless of the region. Tasks performed were observed and listed. Broiler productivity was measured by the overall accumulated flock mortality in each housing facility.

The methodology consisted on the following steps: selection of broiler housings, description of tasks, questionnaire application in interview, accumu- 
lated mortality data collection of the last three flocks housed during the research, and statistical analysis.

For the statistical analysis data were analyzed together using Tukey and Fisher tests for all questions and registered values. Analysis of variance was made using SAS (1985). A descriptive analysis was also performed.

\section{RESULTS AND DISCUSSION}

The tasks performed during broiler production were classified as shown in Table 1 .

An attitude has three components or dimensions: affection, cognition, and behavior (Myers, 2000). The cognitive dimension contains thoughts, information, and beliefs that a person has during an attitude; the affectiveness is associated to emotions related to the object of the attitude; and behavior refers to what the person does related to the object. These dimensions interfere in human attitude. Values and beliefs give in general some directions for human behavior. Beliefs related to work are those that are formed by a group of people, and that express the characteristics of the organization (Company). In animal production, beliefs, attitudes and behaviors have been considered in order to improve animal welfare and to obtain better results in productivity (Rushen et al., 1999; Raussi, 2003; Pajor et al., 2000).

Some specific interactions among workers were identified during the research and several expressions were registered: it is not easy to find wood shavings; it is not easy to find wood during the heating period; the feed ration does not reach the unit on time; the smoke from the heaters irritate eyes; the smell of the heaters difficult my breath; the Company is not worried about us; the supervisor does not listen us; I get sick because of the work. On the other hand there were expressions that demonstrate some emotions related to their work such as: I love the chicklings; it is quite an accomplishment to see them growing; we love the animals; there is always something new to be learned.

From some of the registered complains it was evident that the emotional aspect involving tasks was present and influencing the labor performance of some workers, and generating positive motivation, an important response factor. Hemsworth \& Coleman (1998) define the psychological reaction in animal production as the combination of three components: belief (related to work), affection (towards the animal) and the behavioral tendency (towards the work).

Mitchell \& Kettlewell (2000) enhanced the need animals have to live in conditions that promote free moving, access to health, food and adequate housing. At the same time the worker dealing in tasks directly related to animals is supposed to have a clear perception of fear, hunger and other signs of animal distress.

Regarding the status of human health at work some problems caused mainly by muscle skeletal disorder were detected. From the total sample of workers, 53.7\% presented muscle skeletal disorder (Fisher's test for $\alpha=5 \%$ ), with a weekly frequency and within the last three months of the study. The low back pain was the most reported complain. The continuous tension in a particular type of muscle may result in temporary loss of labor performance or well-being. Some manual activities such as cleaning of drinkers and feeders may lead to back pain. Epidemiological and biomechanical studies suggest that dynamic activities may be related to the presence of low back pain when the performed activities involve repetitive movements (torsions or lateral bending) reducing considerably the

Table 1 - Schedule of tasks performed by the workers during the seven weeks of broiler production.

\begin{tabular}{|c|c|c|c|}
\hline \multirow{2}{*}{ Task } & \multicolumn{3}{|c|}{ Week } \\
\hline & $1-3$ & $3-4$ & $4-7$ \\
\hline Bedding spread over the concrete floor & & & \\
\hline Equipment checking and positioning & --_-_-_-_ & & \\
\hline Assembly of heating circles & & & \\
\hline Receiving one day old chicklings & --------- & & \\
\hline Slaughter of chicklings with problems & & & \\
\hline Counting of chicklings & -------- & & \\
\hline Lateral moving of curtains for controlling inside temperature & & -_-_-_-- & - \\
\hline Checking and cleaning of drinkers and feeders & -------- & -_-_-_-_ & --_-_- \\
\hline Opening of circles & --- & & \\
\hline Bedd revolving & -------- & -_-_-_-- & - \\
\hline \multicolumn{4}{|l|}{ Total removal of circles } \\
\hline Harvest of birds & & & - \\
\hline
\end{tabular}


well-being conditions (Kumar \&Narayan, 1998; Granata \& Marras, 1999).

The relationship between workers and the technical supervisor in region A was tenser then in region B. Comments made and registered were: I see a good result but he never sees it; he does not listen to what I say; he never comments good things I do; he is always negative; and he always complains about our work. On the other hand, comments made in region B were: when we get good results he congratulates; I have no complains about this supervisor; he is a good person; he always finds a better way to work; he always stimulates effort; I give him a straight A.

Satisfaction related to work is an important issue to be considered, and the leader/technical supervisor of the workers has influence on their attitude and behavior. The performance of workers in regions A and B were significantly different (Table 2). The technical supervisor of the region $A\left(S_{1}\right)$ was not able to listen to workers or give them some optimistic view about difficulties, very distinct of supervisor $\left(\mathrm{S}_{2}\right)$ from region $\mathrm{B}$ who was always motivating the workers as well as listening to them.

The results of the regression analysis on worker beliefs are shown in Table 3. Total accumulated broiler mortality index was statistically significant $(\alpha=5 \%)$ in relation to the expressions and beliefs of interviews: a. the results depend on me; b. the Company is serious; c. the broilers suffer; and d. training is needed to grow broilers (Table 3 ).

All coefficients are different from zero for $\alpha$ $=5 \%$, indicating that these beliefs are sources of variation in relation to the accumulated broiler mortality, acting as predictors of the dependent variable. The statistical model found to predict accumulated broiler

Table 2 - Broiler accumulated mortality as a function of the supervision effectiveness.

\begin{tabular}{lcc}
\hline $\begin{array}{l}\text { Technical } \\
\text { Supervisor }\end{array}$ & $\begin{array}{c}\text { Broiler accumulated } \\
\text { mortality }(\%)\end{array}$ & Std deviation \\
\hline $\mathrm{S}_{1}$ & $3.775^{\mathrm{b}}$ & 0.410 \\
$\mathrm{~S}_{2}$ & $3.408^{\mathrm{a}}$ & 0.413 \\
\hline
\end{tabular}

Tukey's test for $\alpha=5 \%$.

Table 3 - Statistical coefficients and their significance.

\begin{tabular}{lccc}
\hline Expressions of belief & Coefficient & Std deviation & P-Value \\
\hline Constant & 3.28 & 0.25 & 0.00 \\
The results depend on me & -0.25 & 0.10 & 0.02 \\
The Company is serious & 0.23 & 0.10 & 0.03 \\
The broilers suffer & 0.34 & 0.07 & 0.00 \\
Training is needed to grow broilers & -0.15 & 0.07 & 0.04 \\
\hline
\end{tabular}

mortality (ABM, \%) as function of the expressions of belief is:

$$
\begin{aligned}
& \mathrm{ABM}=3.28-0.254 \mathrm{a}+0.231 \mathrm{~b}+0.336 \mathrm{c}-0.152 \mathrm{~d} \\
& (\mathrm{~S}=0.569 \mathrm{R}-\mathrm{Sq}=30.5 \% \text { for } \alpha=5 \%) .
\end{aligned}
$$

The definition of satisfaction at work is an emotional reaction around the performed task, resulting in a gain that can be valued and understood by the worker (Cranny et al., 1992). The feelings directly influence motivation towards what happens among people, and attitudes are often related to those feelings (Kolb \& Whishaw, 2002). Thus dissatisfaction on work; poor relation with the technical supervisor; fear of loosing the contract with the integration Company; which were present in the sampling may play a significant role in the final broiler productivity. Waiblinger et al. (2002) carried out a study on general beliefs of workers, like "cows are aggressive", "cows are calm", "cows are hard to deal with", and analyzed the behavior of the workers. They concluded that general beliefs and emotions are capable of predicting some behaviors as "positive" (ex: be gentle) and as "negative" (ex: spank the animal). In general positive attitudes induce to positive behaviors, and negative to negative behavior. Also the animal will respond in the same way, when exposed to positive or negative behavior in relation to them.

\section{CONCLUSIONS}

It was detected that high level of discomfort and lack of dissatisfaction among the workers, and some of their beliefs influenced the final broiler accumulated mortality. It was also found that some specific manual activities may induce lower back discomfort. Results demonstrated that the perception of the work is important and needs to be considered by Companies, as well as the relation between the technical supervisor and the workers who are directly involved with the broiler production since they may influence production. Better understanding of the relations between worker and broiler is still needed in order to better comprehend the whole work environment of broiler production. 


\section{ACKNOWLEDGEMENTS}

To CNPq for providing financial support to this research, and to the Company DaGranja for the research facilities.

\section{REFERENCES}

ALENCAR, M.C.B; NÄÄS, I.; GONTIJO, L.A. Respiratory risks in broiler production workers. Revista Brasileira de Ciência Avícola, v.6, p.23-29, 2004.

BREUER, K.; HEMSWORTH, P.H.; BARNETT, J.L.; MATTHEWS, L.R.; COLEMAN, G.L. Behavioral response to humans and productivity of commercial dairy cows. Applied Animal Behaviour Science, v.66, p.273-288, 2000.

COLEMAN, G.L.; MC GREGOR, M.; HEMSWORTH, P.H.; BOYCE, J.; DOWLING, S. The relationship between beliefs, attitudes and observed behaviours of abattoir personnel in pig industry. Applied Animal Behaviour Science, v.82, p.189200, 2003.

CRANNY, C.J., SMITH, P.C., STONE, E.F. Satisfaction: How people fell about their jobs and how if affects their performance. 1 ed. Lexington Books: New York, 1992. p. 296.

CRANSBERG, P.H.; HEMSWORTH, P.H.; COLEMAN, G.F. Human factors affecting the behaviour and productivity of commercial broiler chicken. British Poultry Science, v.41, p.272-279, 2000.

GRANATA, K.; MARRAS, W. Relation between spinal load factors and high risk of probability of occupational low-back disorder. Ergonomics, v.42, p.1187-1199, 1999.

HARTUNG, J.; SEEDORF, J. Characterization of airborne dust in livestock housing and its effects on animal and environment. In: DUST CONTROL IN ANIMAL PRODUCTION FACILITIES, Horsen, 1999. Proceedings. Horsen: DIAS Danish Institute of Agricultural Sciences, 1999. p.140-153.

HEMSWORTH, P.H. Human-animal interactions in livestock production. Journal of Applied Animal Science, v.81, p.185198, 2003.

HEMSWORTH, P.H.; COLEMAN, G.L. Human-livestock interactions: the stockperson and the productivity and welfare of intensively-farmed animals. Oxon: CAB International, 1998. $178 \mathrm{p}$.
KOLB, B.; WHISHAW, I.Q. Neurociência do comportamento. 1.ed. São Paulo: Manole, 2002. 213p.

KUMAR, S.; NARAYAN, Y. Trunk strength in combined motions of rotation and flexion/ extension in young adults. Ergonomics, v.41, p.835-852, 1998 .

McCOLL-KENNEDY, J.R.; ANDERSON, R.D. Impact of leadership style and emotions on subordinate performance. The Leader Quarterly, v.13, p.545-559, 2002.

MITCHEL, M.A.; KETTLEWELL, P.J. Sistemas de transporte e bem-estar de frangos de corte. In: CONFERÊNCIA APINCO DE CIÊNCIA E TECNOLOGIAS AVÍCOLAS, Campinas, 2000. Anais. Campinas: APINCO, 2000. p.35-39.

MYERS, D.G. Psicologia social. 6.ed. Rio de Janeiro: LTC S.A., 2000.

NÄÄS, I.A; MIRAGLIOTTA, M. Condições de qualidade do ar em granjas de produção de frangos de corte. In: CONGRESSO BRASILEIRO DE ENGENHARIA AGRÍCOLA, 19., Fortaleza, 2000. Proceedings. Fortaleza: CONBEA, 2000. 1 CD-Rom.

PAJOR, E.A.; RUSHEN, J.; DE PASSIÉLLE, A.M. Aversion learning techniques to evaluate dairy cattle handling practices. Journal of Applied Animal Behaviour Science, v.69, p.89-102, 2000.

RAUSSI, S. Human-cattle interactions in group housing. Applied Animal Behaviour, v.80, p.245-262, 2003.

RUSHEN, J.; TAYLOR, A.A.; DE PASSILÉ, A.M. Domestic animal's fear of humans and its effect on their welfare. Journal of Applied Animal Behaviour Science, v.65, p.285-303, 1999.

SAS INSTITUTE. User's guide: Statistics. 5.ed. Cary, NC, 1985.

WAIBLINGER, S.; MENKE, C.; COLEMAN, G. The relationship between attitude, personal characteristics and behaviour of stockpeople and subsequent behavour and production of dairy cows. Applied Animal Behaviour Science, v.79, p.195-219, 2002.

WILSON, J.R.; CORLETT, E.N. Evaluation of human work - A practical ergonomics. London: Taylor and Francis, 1992.

Received June 20, 2005

Accepted October 02, 2006 